\title{
Age Management \\ - Circumstances, Essence and Advantages for Workers and Enterprises
}

Ph.D. Anna Niewiadomska University of Zielona Góra Faculty of Economics and Management

\section{Introduction}

The dynamics of changes taking place in the market environment of companies make their position no longer dependent on the traditional forms of competition such as the prices of products or services. The acquisition, processing and practical implementation of knowledge and skills, experience, innovation of workers is becoming increasingly more and more important. At the same time the amount and age structure of the people constituting workforce resources are subject to gradual transformation as a result of demographic changes taking place in the European societies. One of the most essential consequences of those is the increase in the percentage share of older people in the population, which poses specific challenges for companies. Nowadays employers prefer to employ young people, yet in the nearest future, due to the decrease in their availability, they will be faced with the necessity to engage workers who are more advanced in age. In such circumstances the competitive advantage shall be achieved by the companies who adjust their activity strategies to the forthcoming changes, not only those happening on the market but 
also demographic ones. In West European countries, in which the problem of ageing of the workforce resources appeared a few decades ago, the attention was drawn to the concept of age management related to the idea of active ageing and lifetime training. The aim of this article is to familiarize the reader with the idea of age management and the advantages resulting from its implementation, both for employers and workers.

\section{The essence of the concept of age management}

The changes currently taking place in economy, such as increased competition, rapid implementation of new technologies, introduction of new products onto the market demand from companies the ability to acquire competent workers. This relatively unpredictable environment makes the achievement of the main aim, namely the increase in value, very difficult. As a result, more and more companies notice that their ability to compete will depend not only on their market moves but also on investments in human capital and implementation of the tools of the policy of diversity. In other words, the companies should, for the sake of their own security and position on the market, invest in the solutions that go beyond the standard methods of personnel management. The solution that results from the search for more effective tools of coping with the uncertainty of the environment is diversity management. The idea originated in the USA of 1960s and has become the answer to the changing market reality and growing demand for competent workers. After some time, diversity management was perceived as a way of the optimum use of the presence of the company on a given market and creating opportunities (possibilities) for the development on new markets, as well as removing all types of problems which might lead to the collapse of the company. In the literature on the subject it is currently defined as all activities of an organization whose aim is to consider and utilize diversity in the workplace.[Zarządzanie różnorodnościa 2008 p.6]. In other words it means conscious implementation of specific activities that take the related differences into the account. The diversity is related, among others, to gender, age, race, skills, education and vocational experience.

Age management is treated as one of the elements of diversity management. While analyzing the literature on the subject the two-fold interpretation of the age management concept can be seen. On the one hand, the general aspect of age diverse personnel management is stressed. Such an approach involves the engagement in various activities which allow for more rational and effective use of human resources in companies as a result of acknowledging the needs 
and abilities of workers of different ages (Liwiński, Sztanderska 2010 p. 3). It is concerned with the differing requirements of workers from the respective age groups and appropriate organization of work enabling the use of their potential, knowledge and experience.

On the other hand, due to the progressive ageing of the European societies, age management within companies as the solution that allows the companies to adjust to demographic changes is attracting more and more interest. That is why, in this context, the fulfilment of various activities whose aim is to increase work efficiency of the elderly, and, as a result, also their employability, is stressed. In this view, age management may be defined as solutions whose aim is to ensure constant development, acquisition of knowledge and skills of older workers, sustaining their involvement in the fulfilment of the aims of the company as well as keeping them in good shape and health. (Schimanek 2010 p. 48)

The concept of age management may be analyzed from the perspective of workers, companies or the job market. Age management from the perspective of workers creates the opportunity to extend one's vocational activity, increase one's attractiveness on the job market and increase the possibilities of adaptation to the new technical and technological changes by means of permanent training. Age management as an element of job market involves initiating and undertaking activities that foster the solution of problems related to unfavourable demographic structures (Wiśniewski 2009). Age management for companies is primarily concerned with the activities that increase the awareness of the personnel as to its value as seen from the angle of age and creating age management strategy that would involve recruitment, training, development and promotion of the elderly and lifelong learning (Tokarz 2009).

Due to the fact that age management involves all the activities concerned with the individual needs of workers whose aim is to make the personnel stay with the company as long as possible as well as identify with its aims and operations, it is difficult to think of one pattern for all. Each organization should generally come up with its own path and way of implementing the concept. It is worthadding that there exist certain tools and solutions that can be adjusted to one's strategies. The key issue is that employers realize that activities directed at constant development, updating the knowledge and skills of older workers will lead to tangible benefits. Popularizing the idea of age management might contribute to the change in the way in which mature workers are perceived. Age management might constitute a good investment. The companies involved in its implementation acquire the new image of an employer interested in the vocational development of the elderly workers, which gives them, in the 
longer run, an automatic competitive advantage over those entities that do not acknowledge this form of human resource management.

The fulfilment of the concept of age management may be considered at a few levels, namely those related to an individual, the company and the society. The matrix presented in Figure 1 illustrates the complex approach to the issue of vocational activity of the elderly. The individual levels include problems, ways

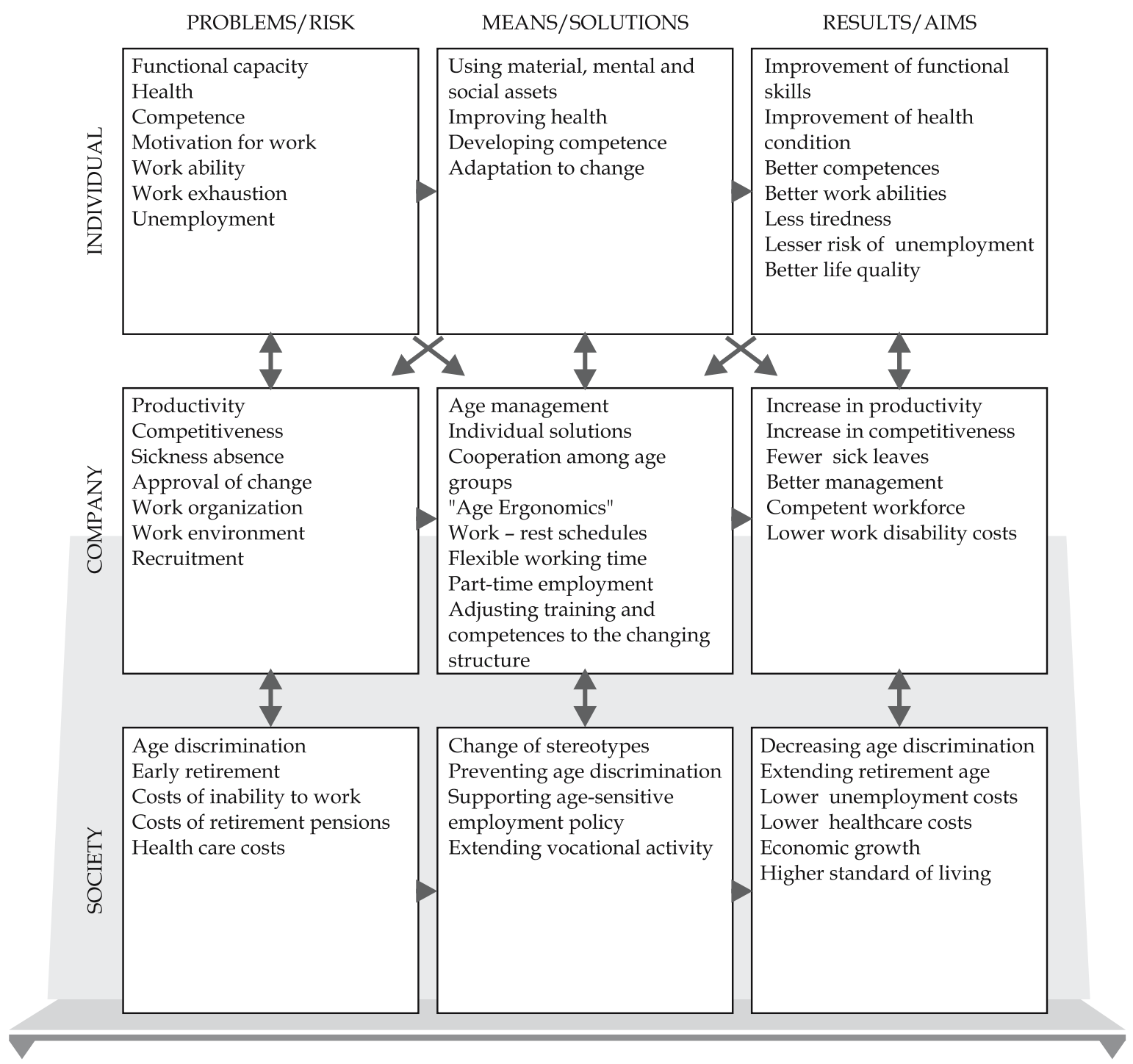

Fig. 1. Matrix of ageing and labour market policy

Source: Ilmarinen 2001 p. 550

Age Management - Circumstances, Essence and Advantages for Workers and Enterprises 
of solving them as well as the potential results from the perspective of workers, companies and society. The arrows connecting the elements of the matrix point to the need for cooperation and interaction between the levels, methods and aims.

The lines of the matrix represent the level of entities, companies and the society, showing that all the groups should share the responsibility for maintaining the vocational activity of the elderly. The methods and ways of solving the problems assigned to such levels might be better planned, which enables the achievement of the appointed goals. Each of the activities requires the engagement of all the participants and their cooperation.

As already mentioned, the close cooperation between workers and the company is crucial as the latter cannot function effectively without the workers. The activities within the scope of the labour market and social policy are also necessary.

Using age management in the company is related to the necessity to consider in daily management the factors connected with age, in particular in the organization of work and individual share of duties so that each worker may fulfil their own aims as well as those of the company.

Age management facilitates the achievement of the following aims (Ilmarinen 2001, Promoting active ageing...p. 2):

- better awareness of ageing,

- positive attitude to ageing,

- age management as the basic responsibility of management and supervisors,

- age management as an element of personnel policy,

- improvement in work ability and efficiency,

- lifetime training,

- elderly-friendly work organization,

- dignified and safe retirement.

Demographic changes currently taking place constitute a challenge not only for the society and job management, but, primarily, for individuals. In most countries action whose aim is to extend the period of professional activity is undertaken. This is related to a number of new questions to which answers must be found. How to motivate and encourage the elderly and experienced workers to pursue further professional activity? How to encourage employers to employ older workers? What factors would facilitate work organization in such a way as to retain experienced and competent workers who are older, in a situation, where economic fluctuations suggest the need for opposite job organization? According to labour market experts the strategy of age management including 
the assets of workers of different ages, using professional experience and competences especially of the elderly, gives the company the opportunity to increase the efficiency and effectiveness of job management. It should be noted that age management as an element of diversity management is a complex process resulting in changes in the culture of the organization. For that reason one should properly prepare for it and treat it as a process of changes in which all the entities important for the organization must be engaged. Additionally the implementation of the concept requires a significant expenditure of time, money and energy.

\section{Premises and areas of age management}

Progressive globalization and the associated increase in market competition are reflected in the rising cost pressure or competition in the scope of acquiring and maintaining qualified workforce. The need for developing appropriate action strategy by companies becomes more apparent in the light of the above. Their interest in age management is usually placed in the context of the restructuring process, market development, organizational changes, lack of workforce or the activity of trade unions.

The recent decades have been the period in which the direction and dynamics of demographic changes have had more and more significance for companies and the job market. A few premises justifying the growing interest in the concept of age management might be listed.

First of all, the change of the age structure of the workforce, in particular the increase in the share of the elderly in it, lead to essential economic consequences for the country, the job market and companies. One of them is the slowdown of the technological progress. As a result of the decrease of young people cooccurring with the increase in the number of older workers, smaller renewability of the work resources can be noted. This limited renewability of the resources connected with the ageing thereof may result in the fall of value of human capital. This is mainly because young workers are perceived as creative individuals constituting the source of new opportunities. Ageing workforce resources are less prone to adjustments to the quickly changing circumstances and conditions. Their mobility and flexibility are decreased, which greatly reduces their ability to adapt to the changes taking place on the job market and they might constitute a problem in gaining the competitive advantage by the companies. These are the potential threats that can be avoided by companies. If specific activities directed at older workers are undertaken, the psychomotor ability that usually

Age Management - Circumstances, Essence and Advantages for Workers and Enterprises 
diminishes with age may not necessarily lead to the lowering of workers' level of competences (Urbaniak 2010: p. 7).

Secondly, it seems that older people constitute the largest available and not yet fully utilized part of the workforce. Workforce ageing combined with relatively early withdrawal of the elderly from the workforce provides yet another stimulus to pursue the country's policy of advocating the idea of age management. In most European countries the need to acquire and retain older workers on the job market is becoming more evident. For many of them the low professional activity of the elderly, especially those who have not yet reached the retirement age is a problem. Employment ratios for older workers (aged 55-64) in EU-27 are currently below 50\%. There are only 15 countries in the world in which the employment of this category is at the level higher than $50 \%$. For many reasons more than a half of older workers resign from their jobs before reaching the statutory retirement age. ( Ilmarinen 2001, Promoting active ageing...p. 2) While the professional inactivity of the elderly combined with the low level of retirement and disability pensions creates a huge risk of marginalization and social exclusion of such persons.

The following are some of the factors that encourage early completion of professional activity by the elderly ( Szatur-Jaworska 2005, p. 21):

- economic and social trends such as unemployment, ageism, pension schemes encouraging relatively early completion of vocational career,

- work organization as well as the technology, pace of work, the necessity to acquire new skills and qualifications, no appropriate training available for workers,

- the characteristics of the elderly, such as the relatively low level of education, health condition, problems with adjusting to the new conditions, tiredness with work and the fear of competition from young persons.

According to experts on human resource management to increase the employment ratio of the elderly, the effects of the activity of the two groups of factors need to be reduced (Walker 1985 pp.211-229, Funk 2004):

- Pushfactors - factors pushing out of employment by means of posing vocational requirements that the elderly cannot meet and their less favourable treatment in comparison with younger workers, e.g. In the area of vocational promotion or access to training.

- Pullfactors - factors pulling out of employment by means of restricting the possibility to retire earlier and creating a strong relationship between retirement pension and age in which it is first collected, which was actually done in the new pension scheme. 
Thirdly, the increased dynamics of ageing of the society leads to an increased interest in age management in companies in the context of preventing discrimination. Preventing age-related discrimination is becoming not only an economic but also a social need. It is reflected in numerous documents of the European Parliament and the Council. In one of them the need to eliminate the phenomenon of discrimination due to age in the scope of employment, vocational education, counselling, which will enable the gradual elimination of negative stereotypes that constitute the basis for such barriers (Council Directive 2000).

Age management is one of the elements of active ageing and lifelong learning. Analyzing the premises of increased interest in the idea, one of the most essential ones needs to be perceived. The change of the age structure of the European societies questions the stability of public pension systems forcing the necessity to restrict retirement benefits and establishing the solutions that will allow the extension of the period of professional activity. In many countries some of such solutions already exist. On the one hand they restrict the possibility of early leaving the labour market, on the other hand they encourage employers to employ older people.

Age management is treated as a tool enabling the use of the potential of the personnel varied in terms of age, on the one hand. On the other hand it is perceived as an instrument whose aim is to increase work efficiency of the elderly and, as a consequence, their employability.

With the development of the age management concept, the following so-called areas of activity were specified.

One of the classifications of the said areas created by EuroLink Age a nongovernmental organization is the European Code of Good Practice. It contains guidelines on good practice in the scope of age management being the effect of consultations carried out with employers, trade unions as well as government representatives. The Code divides the recommended activities into 7 areas (Liwiński, Sztanderska 2010 p. 23):

- recruitment,

- education, training, vocational development and promotion,

- promotion and internal shifts between positions,

- flexible forms of employment and modernization of work,

- designing workplaces and health prevention,

- finishing employment and retirement,

- change of attitude to older workers.

Regardless of the perspective from which age management is analyzed, its significance and relevance to companies will increase due to the direction and 
dynamics of the demographic changes taking place. In spite of the growing knowledge of the subject, an apparent paradox is posed in the activities of companies. On the one hand they are focused on promoting flexible attitudes, open to change, creative, on the other hand they still make use of "stiff" strategies in the areas of recruitment of motivation, creating the barriers in the employment of workers from the specific groups.

\section{Advantages resulting from the realization of age management strategy}

As it has already been pointed out, age management may be perceived in two different dimensions. If analysed from the perspective of the activities undertaken, in the wider dimension they are focused on the long-term activities involving the individual stages of career of individual workers, allowing the thoughtful creation of teams. Its aim is to monitor the professional development of workers in a way that takes into account their skills, prevents burnout and obsolescence of competences, as well as maintains the ability and motivation to work. This comprehensive attitude is related to the creation of multigenerational teams in which the abilities of individual workers are utilized in the best way. In the narrower sense of age management it refers to activities directed specifically at older workers. They are to make their work easier and allow them to make use of their abilities and adjust the conditions to their needs. The following are used to this end, e.g. (Perek-Białas, Strzałkowska, Turek 2010 p. 44):

- ergonomic solutions adjusting the workplaces to health needs and physical requirements,

- flexible working time - part-time employment, individual and flexible working time schedule, restricting in shift-work,

- relevant scope of responsibilities and training.

The awareness of management concerning the influence of the changing age structure of workforce resources on the functioning of companies is essential to the implementation of the strategy of age management. The understanding and acknowledgement of the fact that demographic change is something permanent and inevitable is necessary to build a good and effective age management strategy. Companies that are not interested in the strategy usually lack sufficient knowledge of the topic. In particular they have no understanding as to the potential benefits that the efficient use of age-diverse personnel brings.

At the same time, as the experiences of companies that have noticed the potential proves, the list of the potential benefits can be long. According to J.Fryca and B.Majecka (2010) the benefits include, e.g.: 
- maximising the recruitment potential,

- preventing qualification inefficiencies,

- extending vocational activity of workers,

- retaining key competences,

- longer period of return of costs related to training investments incurred.

Regardless of the changing economic situation such as the current crisis, certain demographic facts will not change but rather deteriorate. Such changes must not be ignored neither by the country in the light of the significant burden on the social insurance nor by employers. Age management might constitute an instrument allowing companies to meet such challenges. In table 1 an exemplary list of benefits that the implementation of age management strategy brings to employers is provided.

\section{Table 1. Advantages related to the implementation of age management in the company}

Advantages related to securing workforce

- More engagement of the workers

- Less stress and tiredness among workers

- Decreased workers' rotation percentage

- Decrease in the amount of previously established pensions.

Results: decrease in the work costs and increased productivity
Advantages related to maximising of workforce efficiency

- Increased participation in learning and training

- Increased ability to innovate

- Increase in the competences of management and supervisory boards

- Better dissemination of knowledge

- Fewer conflicts, better teamwork

Results: increase in the work productivity, organisation competitiveness of the organization and

value of shares

Wider advantages

- Better cooperation between the board and trade unions/ workers' councils

- The development of functions related to human resource management

- Better image among customers.

- Perceiving the organization as the employer from choice

Employers that see the potential of an age-varied team that can skilfully utilize the potential of the elderly may gain a competitive advantage on the market. The review of international experience in the area of age management provides confirmation of a few facts.

Firstly, older workers provide companies with the variety of skills and views and when they are retained in employment, the company is prevented from the 
loss of important skills and experience. Secondly, older workers are the source of experience for younger ones and can transmit the knowledge to them. Thirdly, personnel that is varied in terms of age can better respond to the quickly changing conditions related to globalization. Fourthly, the employment of the elderly and taking care of their vocational development might strengthen the image of the company.

It should be added that creating an age-diverse team facilities the transfer of knowledge in both directions. While older workers teach the young ones the "tricks of the trade" they have gained in the course of long employment, the young ones share their updated knowledge in the scope of e.g. new technological developments. OECD experts characterizing the company of the future in knowledge-based economy predicted that younger workers will be treated as the potential source of new ideas and inspirations while the older ones will be the foundation of the organization's credibility (Knowledge management $2010 \mathrm{pp}$. 58-59).

It seems that the generational balance will be a necessary element of balanced development of companies. The benefits related to the implementation of age management will be felt by workers themselves. The comprehensive approach to the issue increases the motivation of the elderly to stay in employment and perform their tasks in the most effective way. As a result, the period of their vocational activity is increased. In theliterature on the subject such comprehensive approach in the implementation of age management involving the combination of the already mentioned areas is recommended. Then the scope of benefits gained by both employers and employees becomes significantly wider.

\section{Conclusions}

The intensification of globalization as well as the dynamic technological growth over the last decade have resulted in the increase of work efficiency and further development of the international market of workers which partially alleviated the local workforce deficiencies. It created the illusion that the increase in capacity will solve the problem of the temporary lack of workers. There are, however, no illusions as to the direction and dynamics of the demographic changes taking place.

In most European countries the problem of the growing deficiency of the workforce has already appeared or will appear in the near future. The loss of qualified and experienced workforce, in particular in the areas with a large share of older workers, might initiate the fall in economic growth. In such a situation the creation of the adequate strategy of the management of human resources, in 
which the said demographic changes are acknowledged, becomes the necessity. Age management is concerned with planning such solutions in the management of human resources that will make the company friendly to the more mature workers and enable it to fully use the potential of the workers at different ages. Consequently it might be perceived as an instrument enabling the company to maintain its market position in the conditions of workforce ageing. Additionally the use of age management fosters the creation and strengthening the image of the company as the organization that is socially responsible and interested in the development of its workers.

\section{Summary}

Keywords: age management, ageing society, professional activity

\section{Age Management - Circumstances, Essence and Advantages for Workers and Enterprises}

The demographic forecasts that have been published for many years point to the growing dynamics of the ageing process of the European societies. One of its consequences is the shrinking population of young people and the growing average age of workers. In the light of the forecast deficiency and growing of the resources of workforce the concept of age management in the company is becoming more popular. This paper familiarizes the reader with the essence of age management, presenting its main premises, scopes of activity and benefits resulting from its use.

\section{Streszczenie}

Zarządzanie wiekiem- przesłanki, istota oraz korzyści dla pracowników i przedsiębiorstw

Publikowane od wielu lat prognozy demograficzne zwracają uwagę na rosnącą dynamikę procesu starzenia się społeczeństw europejskich. Jedną z jego konsekwencji jest kurczenie się populacji ludzi młodych oraz rosnąca średnia wieku pracowników. W obliczu prognozowanego deficytu oraz starzenia się zasobów siły roboczej rośnie zainteresowanie koncepcją zarządzania wiekiem w przedsiębiorstwie. Niniejszy artykuł przybliża istotę zarządzania wiekiem prezentując główne jego przesłanki, obszary

\section{Słowa}

działań oraz korzyści płynące z jego zastosowania.

kluczowe: $\quad$ zarządzanie wiekiem, starzenie się społeczeństwa, aktywność zawodowa 


\section{References}

1. Directive of the Council 2000/78/EC of 27 November 2000 establishing the general framework conditions on equal treatment in the scope of employment and work Official Journal L $303,02 / 12 / 2000$ P.

2. Fryca J., Majecka B. (2010), Istota zarzadzania wiekiem w przedsiębiorstwie, "Newslatter" nr. 8, Gdańsk.

3. Funk L. (2004), Employment Opportunities for Older Workers: A Comparison of Selected OECD Countries, DICE Research Report.

4. Ilmarinen J.(2001), Aging worker, Occupational and Enviromental Medicine August.

5. Ilmarinen J., Promoting active ageing in the work place, http:/ / osha.europa. eu/en/publications / articles/promoting-active-ageing-in-the-workplace, ( 20.07.2012).

6. Knowledge management in the Learning Society (2010), OECD, Paris.

7. Liwiński J.Sztanderska U. (2010), Zarzadzanie wiekiem w przedsiębiorstwie, Uniwersytet Warszawski, Warszawa.

8. Perek-Białas J., Strzałkowska H., Turek K. (2010), Analiza desk research w ramach badań dot. stworzenia modelu świadczenia ustug doradztwa i rozwoju kariery pracowników 50 + Pracownia Badań Społecznych, Kraków.

9. Schimanek T. (2010), Co to jest zarządzanie wiekiem? in: Aktywizacja zawodowa osób 50+ i zarządzanie wiekiem. Akademia Rozwoju Filantropii w Polsce, Warszawa.

10. Szatur-Jaworska B. (2005), Co wiemy o dyskryminacji ze względu na wiek? Głos ekspertów, doświadczenia osób starszych, Akademia Rozwoju Filantropii w Polsce, Warszawa.

11. Taylor P. (2006), Employment initiatives for an ageing workforce in the EU15, European Foundation for the Improvement of Living and Working Conditions.

12. Tokarz J. (2009), Efektywne zarządzanie wiekiem. Biuletyn Euro Info nr 109 Warszawa.

13. Urbaniak B.(red) (2007), Pracownicy 45+ w naszej firmie, Warszawa.

14. Walker A. (1985), Early Retirement: Release or Refuge from the Labour Market?, "The Quarterly Journal of Social Affairs", 1(3).

15. Wiśniewski Z. (2009), Zarządzanie wiekiem w organizacjach wobec procesów starzenia się ludności, TNOi K Torun.

16. Zarządzanie różnorodnościa (2008), Materiały dla osób uczestniczących w Forum Odpowiedzialnego Biznesu, Warszawa. 